\author{
А. П. Горбата, \\ аспірант кафедри публічного управління та менеджменту \\ інновачійної діяльності ННІ неперервної освіти і туризму, \\ Начіональний університет біоресурсів і природокористування України \\ ORCID ID: 0000-0003-4487-6357
}

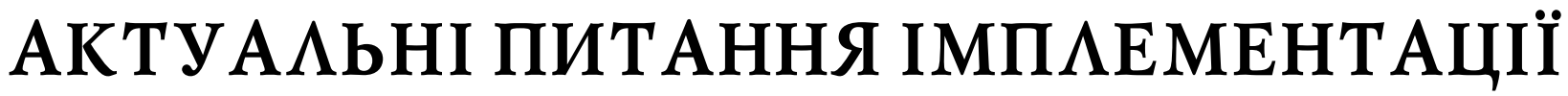 ПРИНЦИПІВ МІЖНАРОАНОЇ ХАРТІЇ ВIАКРИТИХ ААНИХ В УКРАЇНI
}

\author{
L. Gorbata, \\ Postgraduate student of the Department of public management and innovation management, \\ UI of continuing education and tourism, National University of Life and Environmental Sciences of Ukraine
}

\section{CURRENT ISSUES OF IMPLEMENTATION OF THE PRINCIPLES OF THE INTERNATIONAL OPEN DATA CHARTER IN UKRAINE}

У статті досліджено Міжнародну хартію відкритих даних, що спрямована на забезпечення співпраці з прийняття та реалізації спільних принципів, стандартів і кращих практик оприлюднення та використання відкритих даних у більшості країн світу. Проаналізовано нормативноправову базу, що створює підгрунтя для доступу до публічної інформації у формі відкритих даних в Україні. Охарактеризовано принципи оприлюднення наборів відкритих даних та розкрито їх змістовне навантаження. Конкретизовано набори відкритих даних для кожного розпорядника публічної інформації і порядок щорічної оцінки стану оприлюднення та оновлення відкритих даних розпорядниками інформації на Єдиномудержавному веб-порталі відкритих даних. Акцентовано увагу на дотриманні права інтелектуальної власності на інформацію та інструментах забезпечення цього права під час оприлюднення публічної інформації. Розглянуто діяльність дванадцяти міських рад в Україні, які у 2017-2020 роках приєдналися до Міжнародної хартії відкритих даних, взявши на себе зобов'язання з розкриття важливих для своїх громад даних, зокрема, про надходження та використання коштів місцевого бюджету, фінансову звітність, відомості про заплановані ремонтні роботи, перелік об'єктів комунальної власності. Проаналізовано кількісні показники наборів даних цих дванадцяти міських рад, які оприлюднені на Єдиному державному веб-порталі відкритих даних та зроблено висновок про те, що ці органи влади демонструють не лише високі показники розвитку політики відкритих даних, а й очолюють рейтинги прозорих міст. Акцентовано увагу на невідповідності кількісних показників оприлюднених наборів даних на Єдиному державному веб-порталі відкритих даних і власних Порталах відкритих даних органів публічної влади, що пов'язано з великою кількістю інформації на Порталах органів публічної влади, яка не відповідає вимогам до якості публічної інформації, що може бути оприлюдненою на Єдиномудержавному веб-порталі відкритих даних. Розкрито проблему, яка потребує негайного законодавчого врегулювання щодо безконтрольного збільшення кількості та дублювання сайтів і вимогдо публікацій.

3'ясовано, що політика відкритих даних, яка складається з системи цілей, заходів та інструментів, спрямованих на стале використання відкритих даних управлінцями, підприємцями та громадськістю реалізується через електронні сервіси, додатки тощо. Запропоновано рекомендації щодо впровадження принципів Міжнародної хартії відкритих даних у діяльність органів публічної влади в Україні. 
The article examines the International Open Data Charter, which aims to ensure cooperation in the adoption and implementation of common principles, standards and best practices for the disclosure and use of open data in most countries. The legal framework that creates the basis for access to public information in the form of open data in Ukraine is analyzed. The principles of publication of open data sets are described and their content load is revealed. The sets of open data for each public information manager and the procedure for annual assessment of the state of publication and updating of open data by information managers on the Unified State Web Portal of Open Data have been specified. Emphasis is placed on the observance of intellectual property rights to information and tools to ensure this right during the disclosure of public information. The activity of twelve city councils in Ukraine, which joined the International Open Data Charter in 2017-2020, undertook to disclose important data for their communities, in particular, on the receipt and use of local budget funds, financial statements, information on planned repair works, list of objects of communal property. The quantitative indicators of the data sets of these twelve city councils, which were published on the Unified State Web Portal of Open Data, were analyzed and it was concluded that these authorities show not only high indicators of open data policy development, but also top the rankings of transparent cities. Emphasis is placed on the inconsistency of quantitative indicators of published datasets on the Unified State Web Portal of Open Data and own Public Data Portals of public authorities, which is due to the large amount of information on the Portals of public authorities that does not meet the requirements for quality of public information. may be published on the Unified State Web Portal of Open Data. An issue has been identified that requires immediate legislative regulation regarding the uncontrolled increase in the number and duplication of sites and publication requirements.

It was found that the open data policy, which consists of a system of goals, measures and tools aimed at the sustainable use of open data by managers, entrepreneurs and the public is implemented through electronic services, applications, etc. Recommendations for the implementation of the principles of the International Open Data Charter in the activities of public authorities in Ukraine are offered.

Ключові слова: публічне управління, Відкриті дані, інформаційна Відкритість, принципи відкритих даних, Міжнародна хартія Відкритих даних, органи публічної Влади.

Key words: public administration, open data, information openness, principles of open data, International Charter of Open Data, public authorities.

\section{ПОСТАНОВКА ПРОБАЕМИ}

Україна успішно розвиває політику відкритих даних щодо діяльності органів публічної влади, їх посадових осіб, відкритості і прозорості прийняття управлінських рішень, залучення представників громадськості та бізнесу. Міжнародні організації відзначають високий рівень зрілості в цьому напрямі. За підсумками рейтингу Open Data Maturity Report 2020, який опубліковано 16 грудня 2020 року на Європейському порталі даних (EDP) щодо рівня розвитку сфрери відкритих даних, Україна посіла 17 місце та увійшла до переліку країн, що швидко розвиваються (Fast-trackers), набравши 2180 балів із 2600 можливих. Оцінювалася державна політика, фрунціонал національного порталу відкритих даних, якість наборів та вплив відкритих даних. За всіма показниками Україна продемонструвала вищі результати, ніж середні у Європі. Навіть за показниками державної політики Україна набрала 554 бали, або 85\%, що відповідає країнам ЄС, де середній показник - 85\% [22].
Відповідно до критеріїв рейтингу аналітики дослідили відповідність законодавства міжнародним стандартам, державну стратегію щодо розвитку сорери відкритих даних на національному та місцевих рівнях, а також - які ініціативи впроваджуються для розвитку навичок державних службовців, що працюють із даними, та спільноти щодо використання цих даних. Високо оцінено фрунціонал Єдиного державного вебпорталу відкритих даних (https://data.gov.ua), сталість його розвитку, частоту оновлення даних на порталі, а також рівень його використання. За 2020 р. аудиторія порталу зросла у півтора рази і налічує понад 1 млн користувачів. За показниками впливу відкритих даних у різних сорерах, а саме: економічній, державного управління, соціальній, екологічній (550 балів, або 85\%) балів Україні додали проєкти на основі даних, зокрема переможці національного конкурсу Open Data Challenge, що активно розвивають рішення; а також проведенні якісні досліджень щодо впливу відкритих даних, зокрема у 
будівельній сфері, будівництва та ремонту доріг, охорони здоров'я, які проводяться Міністерством цифрової трансорормації та міжнародним проєктом USAID/ UK aid "Прозорість та підзвітність у державному управлінні та послугах/TAPAS" [1]. Проте, незважаючи на суттєві успіхи у сорері запровадження відкритих даних, $€$ різні суб'єктивні та об'єктивні причини, що утруднюють процеси їх запровадження, саме на аналіз та узагальнення цих причин спрямоване це дослідження.

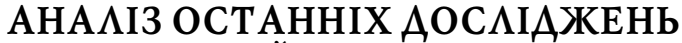 І ПУБ $А$ АЦИЙ}

Проблематику відкритості даних розглядали Е. Афонін, Ю. Габермас, І. Грищенко, Н. Гудима, Д. Гунін, В. Мельниченко, $Є$. Тихомирова, А. Серенок та ін. Інноваційні сервіси відкритих даних для забезпечення ефективного функціонування е-Уряду у своїх працях висвітлювали П. Клімушин і Д. Спасібов. Відкриті дані як інструменти інфоормаційного забезпечення прозорості публічної влади досліджували М. Дурман, І. Тохтарова. Тема дослідження відкритості $€$ актуальною і серед зарубіжних науковців. Зокрема, дослідник Тім БернерсЛі репрезентував п'ятизіркову схему розгортання для відкритих даних. Візуалізацію відкритих даних розвинув Е. Саммерс, курс відкритих даних для програмістів розробив К. Гаттерідж, а К. Форсберг запропонував підсвічування відкритих даних.

Науковці акцентували увагу на різних аспектах забезпечення відкритості органів влади, проте наукових напрацювань щодо реалізації принципів Міжнародної хартії відкритих даних немає. Праця безпосередньо пов'язана з науковими дослідженнями кафедри публічного управління та менеджменту інноваційної діяльності Національного університету біоресурсів і природокористування України, які здійснюються в межах науководослідної теми "Теоретичні засади і механізми реалізації інноваційних процесів у публічному управлінні" (ДР №118U100146).

\section{META I ЗАВААНHЯ СТАTTI}

Мета статті - проаналізувати принципи Міжнародної хартії відкритих даних та сорормувати рекомендації щодо їх впровадження у діяльність органів публічної влади в Україні.

Виходячи з мети, у роботі поставлено такі завдання:

- виокремити й узагальнити основні напрями діяльності органів публічної влади з реалізації принципів Міжнародної хартії відкритих даних;

- окреслити основні шляхи та визначити проблемні аспекти щодо впровадження принципів Міжнародної хартії відкритих даних у діяльність органів публічної влади в Україні.

\section{ВИК ААА ОСНОВНОГО МАТЕРІААУ}

У світі спостерігається значна глобальна трансформація, якій сприяють технології та цифрові медіа, а також дані та інформація. Ця трансформація має величезний потенціал для сприяння більш ефективним, прозорим, підзвітним, та дієвим урядам, громадянським суспільствам та організаціям приватного сектору. Відкриті дані є центром цього глобального зрушення. Як зазначає І. Грищенко в статті "Програма діяльності Кабінету
Міністрів України в аспекті консолідації та розвитку української нації" - "це концепція державотворення, вихідна позиція національного інтересу та національної безпеки" [4, с. 34], оскільки побудова більш справедливого та процвітаючого суспільства можлива за умови прозорості та підзвітності урядів, а також їх регулярної та змістовної взаємодії з громадянами. Водночас триває глобальна революція даних. Вїї результаті розвивається співпраця навколо ключових соціальних проблем, забезпечується ефективність громадського контролю за діяльністю уряду. Виникає краща можливість для дієвих, ефективних державних програм [10].

Міжнародна хартія відкритих даних (далі - Хартія) це міжнародна ініціатива, що сприяє співпраці, прийняттю та реалізації спільних принципів, стандартів і найкращих практик оприлюднення та використання відкритих даних у всьому світі. У 2016 р. Україна приєдналася до Хартії і, відповідно, урядом було розроблено та схвалено план дій з реалізації її принципів, стандартів та кращих практик відкритих даних [5].

Низка нормативно-правових актів, попередньо напрацьованих урядом, створили необхідне правове підгрунтя. У Законі України "Про внесення змін до деяких законів України щодо доступу до публічної інформації у формі відкритих даних" від 25 грудня 2015 р. № 922-VIII визначено понятт публічної інформації у формі відкритих даних. Це публічна інформація у форматі, що дозволяє: автоматизоване оброблення електронними засобами; вільний та безоплатний доступ до неї; безперешкодне її подальше використання [19]. Серед важливих підзаконних актів, що регулюють питання відкритих даних - Постанова Кабінету Міністрів України № 835 від 21 жовтня 2015 р. "Про затвердження Положення про набори даних, які підлягають оприлюдненню у формі відкритих даних" [18] та Постанова Кабінету Міністрів України від 20 грудня 2017 р. № 1100 "Про внесення змін до Положення про набори даних, які підлягають оприлюдненню у формі відкритих даних", яка вносить значні зміни до врегулювання сфрери відкритих даних, а саме додано основні принципи оприлюднення наборів даних у формі відкритих даних: відкритість за замовчуванням; оперативність ічіткість; доступність і використання; порівнянність та інтероперабельність; покращене урядування і залучення громадян; інклюзивний розвиток та інновації [6; 8; 20; 21], які задекларовано у Хартії.

Принцип "відкритість за замовчуванням" передбачає відкритість публічної інформації, за винятком випадків визначених законодавством. Розпорядники інформації, відкриваючи нові набори даних, мають забезпечити захист персональних даних, іншої інфрормації з обмеженим доступом.

Принцип "оперативність та чіткість" полягає в актуальності відкритих даних. Важливо оперативно оновлювати первинні вечерпні дані, одразу після змін.

Принцип "доступність і використання" відкритих даних має декілька аспектів: по-перше, оприлюднення даних у машиночитаних форматах дає можливість для їх автоматизованого збору та обробки; по-друге, користувачі мають легко знаходити необхідну інфрормацію; по-третє, дані мають бути безкоштовними та мати відкриті ліцензії. 


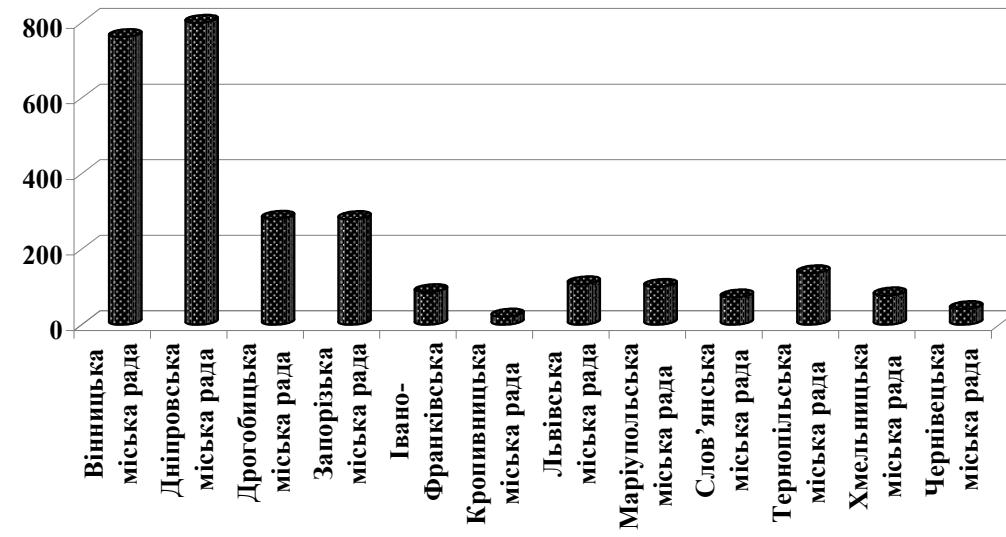

\section{Рис. 1. Кількісні показники наборів даних, які оприлюднено на Єдиному державному веб- порталі відкритих даних станом на 10.02.2021}

Джерело: побудовано автором на основі даних [7].

Принцип "порівнюваності та інтероперабельності" (можливість поєднання з іншими даними) передбачає можливість комбінувати та поєднувати різні види даних, значно підвищує їх цінність.

Прозорість та підзвітність забезпечує принцип "покращене урядування і залучення громадян". Упровадження електронних сервісів спрощує процедуру участі громадян у прийнятті управлінських рішень, сприяє розвитку демократичного суспільства.

Для покращення інклюзивного економічного розвитку надає можливості принцип "інклюзивний розвиток та інновації". Наприклад, на основі відкритих даних представники бізнесу мають можливість створювати нові ІТ-продукти (сервіси, мобільні додатки).

Відповідно до Постанови Кабінету Міністрів України від 17 квітня 2019 р. № 409 "Про внесення змін до деяких постанов Кабінету Міністрів України щодо відкритих даних" у Переліку наборів даних, які підлягають оприлюдненню у формі відкритих даних конкретизовано набори даних для кожного розпорядника інформації на усіх рівнях управління; визначено порядок щорічної оцінки стану оприлюднення та оновлення відкритих даних розпорядниками інформації на Єдиному державному веб-порталі відкритих даних [18].

Для вільного і безоплатного доступу користувачів до інформації законодавство надає всі можливості. Але щодо права інтелектуальної власності на інформацію, якою володіють розпорядники, існує застереження: обов'язкове посилання на джерело отримання інорормації (у тому числі гіперпосилання на веб-сторінку відкритих даних розпорядника інформації).

Належні процедури діловодства дають низку гарантій, зокрема на достовірність і надійність інформації, на її легке і швидке отримання, збереження протягом визначеного часу. Також належне діловодство дає можливість безпечного та правильного розпорядження іноормацією, гарантує надійний захист, якщо вона приватна або конфріденційна [3; 21].

У 2017 -2020 рр. 12 органів публічної влади з України приєдналися до Міжнародної хартії відкритих даних. А саме - Вінницька міська рада, Дніпровська міська рада, Дрогобицька міська рада, Запорізька міська рада, Івано-Франківська міська рада, Кропивницька міська рада, Львівська міська рада, Маріупольська міська рада, Слов'янська міська рада, Тернопільська міська рада,
Хмельницька міська рада, Чернівецька міська рада [10]. Ці органи публічної влади взяли на себе зобов'язання щодо розкриття важливих даних для своїх громад, наприклад - про розподіл коштів місцевого бюджету, фрінансову звітність, відомості про заплановані ремонтні роботи, перелік об'єктів комунальної власності.

Розвиток політики відкритих даних на місцевому та регіональному рівнях сприяє підвищенню рівня прозорості та відкритості діяльності органів публічної влади; спрощує доступ громадян до необхідної інфрормації чи послуг; стимулює розвиток інновацій в малому та середньому бізнесі за рахунок створення нових проєктів і сервісів на основі відкритих даних; сприяє створенню робочих місць через генерування та використання інтелектуального потенціалу.

Приєднавшись до Хартії, органи публічної влади беруть на себе зобов'язання:

- напрацювати нормативну базу (положення про відкриті дані, посадові інструкції, порядки, ведення та оприлюднення реєстрів);

- створити структурний підрозділ або закріпити посадову особу у сорері управління даними;

- підвищити кваліфікацію посадових осіб з оприлюднення та використання даних;

- провести аудит відкритих даних, сорормувати реєстр відкритих даних органу публічної влади;

- модернізувати інформаційні системи для експорту даних у відкритих машиночитаних фрорматах;

- налагодити комунікацію між структурними підрозділами органу публічної влади;

- впровадити електронні сервіси;

- провести консультації з представниками бізнесу та громадськістю щодо відкриття наборів даних, підвищення їх якості;

- впровадити місцевий портал відкритих даних;

- просувати та популяризувати відкриті дані шляхом проведення хакатонів, конкурсів відкритих даних та інших заходів.

Органи публічної влади, які приєдналися до Хартії, демонструють не тільки високі показники розвитку політики відкритих даних, а й очолюють рейтинги прозорих міст, розпорядників інформації, що оприлюднили найбільшу кількість наборів даних на Єдиному державному веб-порталі відкритих даних. Найбільше наборів даних оприлюднено Дніпровською міською радою (799 на- 


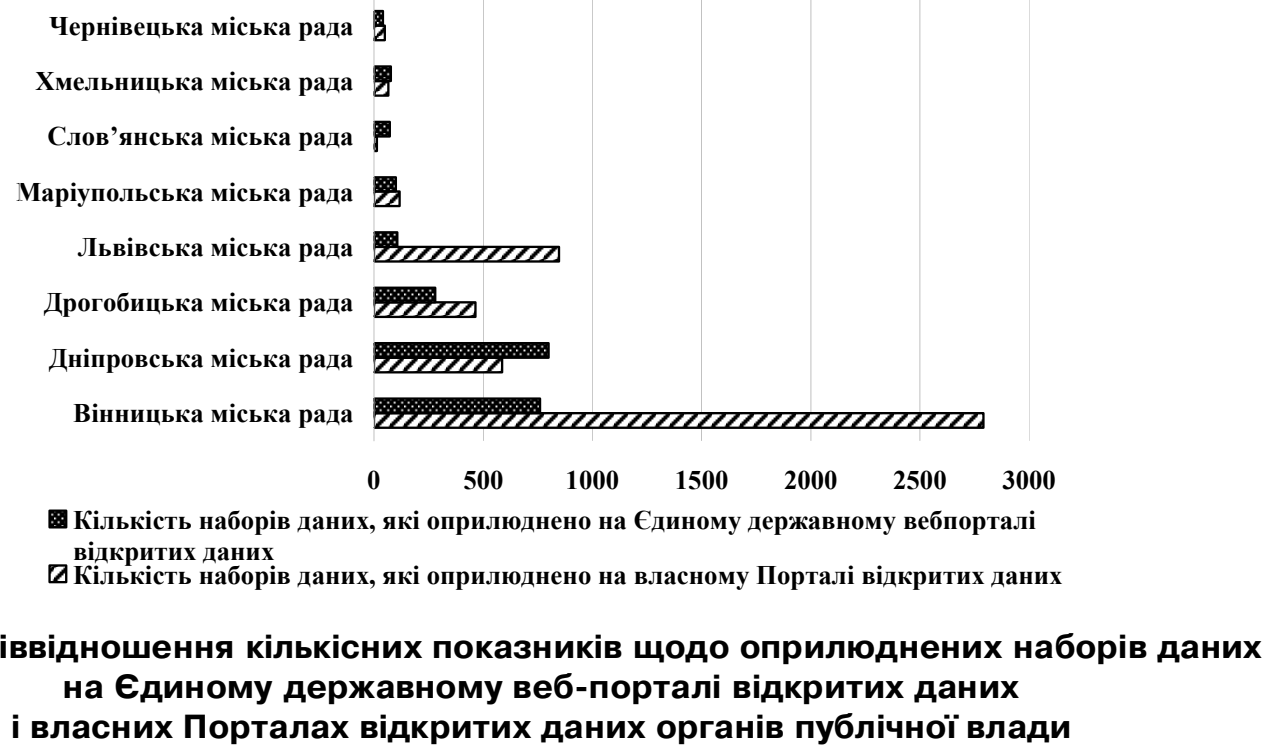

Джерело: побудовано автором на основі даних [7; 2; 11-17].

борів даних), Вінницькою міською радою (761 набір даних), Дрогобицькою міською радою (280 наборів даних) та Запорізькою міською радою (279 наборів даних). Найменша кількість наборів даних оприлюднено Кропивницькою міською радою (21 набір даних) та Чернівецькою міською радою (41 набір даних) (рис. 1).

8 з 12 органів публічної влади створили власні портали відкритих даних, а саме: Вінницька міська рада, де оприлюднено 2790 наборів даних [11]; Дніпровська міська рада, 587 наборів даних [12]; Дрогобицька міська рада, 464 набори даних [13]; Львівська міська рада, 848 наборів даних [2]; Маріупольська міська рада, 117 наборів даних [14]; Слов'янська міська рада, 14 наборів даних [15]; Хмельницька міська рада, 65 наборів даних [16]; Чернівецька міська рада, 49 наборів даних [17].

Співвідношення кількісних показників оприлюднених наборів даних на Єдиному державному веб-порталі відкритих даних і власних Порталах відкритих даних органів публічної влади (рис. 2) показує, що на власних порталах органи публічної влади оприлюднюють значно більше наборів даних, ніж на Єдиному державному веб-порталі відкритих даних. На нашу думку, це пов'язано з великою кількістю "брудних" даних, які створюють окремі структурні підрозділи та комунальні підприємства органів публічної влади. Їх якість $€$ низькою, тому такі набори даних не можуть бути оприлюднені на $€_{\text {ди- }}$ ному державному веб-порталі відкритих даних.

Слов'янська, Хмельницька та Чернівецька міські ради тільки починають розвивати політику відкритих даних, тому їх кількість $€$ ще низькою порівняно 3 Вінницькою, Львівською та Дрогобицькою міськими радами.

Політика відкритих даних (система цілей, заходів та інструментів) спрямована на стале використання відкритих даних управлінцями, підприємцями та громадськістю. На основі відкритих даних органи публічної влади реалізовують електронні сервіси, додатки. Наприклад, у Маріупольській міській раді працює п'ять таких інструментів:

- "Маріупольський транспорт" - це веб-сервіс для пошуку маршрутів громадського транспорту, перегля- ду їх графріків руху та інформації про місцезнаходження у режимі реального часу;

- офріційний геопортал Маріупольської міської ради впроваджено з метою забезпечення доступу громадян до геопросторової та іншої інорормації, розпорядниками якої $€$ виконавчі органи Маріупольської міської ради, підвищення рівня оперативності та ефективності прийняття управлінських рішень виконавчими органами міської ради, оцифрування внутрішніх процесів та автоматизації процесу ведення реєстрів, оприлюднення, оновлення та забезпечення доступу до публічної інфрормації у формі відкритих даних;

- "Медицина Маріуполя в цифрах" - це інтерактивний дашборд про роботу системи охорони здоров'я, проєкт про роботу та фрінансування комунальних закладів охорони здоров'я, надходження та використання благодійної допомоги медичними установами. Сервіс допоможе громадянам обрати сімейного лікаря, дасть рекомендації щодо діагностики стану здоров'я;

- "Медичний портал Маріуполя (MedKontrol)" проєкт, що дає змогу зробити сореру охорони здоров'я відкритою й доступною для мешканців міста, допомогти пацієнтам з вибором сімейного або профрільного лікаря, надати довідкову інфрормацію про обстеження, аналізи та ліки. Важливою функцією порталу є підвищення рівня медичної грамотності громадян та їх обізнаності щодо профілактики захворювань;

- "CityBot Назар" - швидкий та зручний канал отримання своєчасної інформації про поточні ремонти та строки усунення аварій.

Сервіс "CityBot Назар" використовують 7 органів публічної влади, а саме: Маріупольська, Бердянська, Запорізька, Дрогобицька, Тернопільська, Луцька, Славутицька міські ради [9].

Але впровадження принципів Міжнародної хартії відкритих даних в Україні має низку перешкод, а саме: консерватизм у діяльності органів публічної влади; нестача цифрової компетентності публічних службовців та громадян, що спостерігається у малих населених пунктах; несвоєчасність розміщення наборів даних на порталах; недостатнє покриття широкосмуговим Інтерне- 
том, причиною цього часто $є$ проблеми з фрінансуванням; необхідність удосконалення інформаційних систем та механізмів управління у сорері відкритих даних.

Серйозною проблемою $є$ безперервне збільшення кількості та дублювання сайтів, де публікуються відкриті дані: кожна установа формує свої правила публікації та організовує власні сервіси публікацій. Таким чином, сервіси стають автентичними і несумісним між собою. Це суттєво ускладнює розробку сервісів на основі цих технічно різних наборів та призводить до збільшення вартості розробки продуктів на основі відкритих даних. У результаті впровадженя концепту відкритих даних втрачає свою актуальність та зрештою й ефективність.

\section{ВИСНОВКИ}

Отже, відкритими можна вважати дані, які відповідають певним якісним критеріям, що зробить їх використання або аналіз доступними. Під час роботи з відкритими даними розпорядники мають усвідомлювати важливість розміщення відкритих даних, зважати на кількість і якість наборів відкритих даних, знати основні принципи відкритих даних та спиратися на стандарти їх оприлюднення.

Проблемними аспектами застосування принципів Міжнародної хартії відкритих даних у діяльності органів публічної влади $є$ недосконалість контролю та моніторингу оприлюднення відкритих даних. А також та обставина, що за неоприлюднення чи неналежне оприлюднення відкритих даних розпорядники не несуть відповідальності.

Виходячи з проведеного аналізу впровадження принципів Хартії відкритих даних в Україні, можна запропонувати темами подальших наукових досліджень нормативно-правове забезпечення аудиту відкритих даних, закріплення відповідальності за неоприлюднення органами публічної влади відкритих даних, з'ясування їх впливу на окремі сфрери управлінської діяльності.

\section{Література:}

1. Веб-ресурс проєкту USAID/UK aid "Прозорість та підзвітність у державному управлінні та послугах". URL: https://tapas.org.ua/all-uk (дата звернення: 14.02.2021).

2. Відкриті дані Львова. URL: https:/ /opendata.cityadm.Iviv.ua (дата звернення: 14.02.2021).

3. Грищенко І.М., Горбата Л.П. Пріоритетні напрями і шляхи забезпечення інформаційної відкритості в органах публічної влади. Public and municipal administration: theory, methodology, practice: Collective monograph. Riga: Izdevnieciba "Baltija Publishing", 2020. 318 р. С. $20-39$.

4. Грищенко І. Програма діяльності Кабінету Міністрів України в аспекті консолідації та розвитку української нації. Збірник наукових праць Національної академії державного управління при Президентові України. 2020. Вип. 1. С. 33-40. DOI 10.36.030/2664-3618-2020-1-3340. URL: http://zbirnyk-nadu.academy.gov.ua/article/ view /208994/209142 (дата звернення: 14.02.2021).

5. Деякі питання приєднання до Міжнародної хартії відкритих даних: Розпорядження Кабінету Міністрів України від 22 вересня 2016 р. № 686-p. URL: https:// zakon.rada.gov.ua/laws/show /686-2016-\%D1\%80\#Text (дата звернення: 14.02.2021).

6. Дурман М.О. Відкриті дані як інструмент інфрормаційного забезпечення прозорості публічної влади. Теорія та практика державного управління і місцевого самоврядування. Херсон, 2017. № 1. URL: http:// nbuv.gov.ua/j-pdf/Ttpdu_2017_1_15.pdf (дата звернення: 14.02.2021).

7. Єдиний державний веб-портал відкритих даних. URL: http://data.gov.ua (дата звернення: 14.02.2021).

8. Національний інститут стратегічних досліджень. Основні принципи використання та доступу до публічної інформації у формі відкритих даних: зарубіжний досвід для України: аналіт. зап. URL: http:// www.niss.gov.ua/articles/2297 / (дата звернення: 14.02.2021).

9. Сайт "CityBot Назар. Міський бот". URL: https:/ /citybot.pro (дата звернення: 14.02.2021).

10. Офіційний веб-сайт Міжнародної хартії відкритих даних. URL: https://opendatacharter.net/government-adopters (дата звернення: 14.02.2021).

11. Портал відкритих даних Вінниці. URL: https:// opendata.gov.ua (дата звернення: 14.02.2021).

12. Портал відкритих даних Дніпровської міської ради. URL: https://opendata.dniprorada.gov.ua (дата звернення: 14.02.2021).

13. Портал відкритих даних Дрогобицької міської ради. URL: https://opendata.drohobych-rada.gov.ua (дата звернення: 14.02.2021).

14. Портал відкритих даних Маріупольської міської ради. URL: https:/ /data.mariupolrada.gov.ua (дата звернення: 14.02.2021).

15. Портал відкритих даних Слов'янської міської ради. URL: https:/ /opendata.slavrada.gov.ua (дата звернення: 14.02.2021).

16. Портал відкритих даних Хмельницької міської ради. URL:https://mycity.khm.gov.ua/OpenData (дата звернення: 14.02.2021).

17. Портал відкритих даних Чернівців. URL: https: / /data.city.cv.ua (дата звернення: 14.02.2021).

18. Про затвердження Положення про набори даних, які підлягають оприлюдненню у формі відкритих даних: Постанова Кабінету Міністрів України від 21 жовтня 2015 р. № 835. URL: https://zakon.rada.gov.ua/ laws /show /835-2015-\%D0\%BF\#Text (дата звернення: 14.02.2021).

19. Про внесення змін до деяких законів України щодо доступу до публічної інфрормації у фрормі відкритих даних: Закон України від 25 груд. 2015 р. № 922VIII. URL: http://zakon.rada.gov.ua/go/319-19 (дата звернення: 14.02.2021).

20. Про внесення змін до Положення про набори даних, які підлягають оприлюдненню у формі відкритих даних: Постанова Кабінету Міністрів України від 20 груд. 2017 p. № 1100. URL: http://zakon5.rada.gov.ua/laws / show /1100-2017-п (дата звернення: 14.02.2021).

21. Mykola O. Semenyshyn, Iryna M. Hryshchenko, Kateryna A. Alekseieva, Volodymyr V. Oliinyk, Hanna S. Buha. Research of features of professional selfactualization of civil servants through the determinants of information security. Revista San Gregorio. Num. 42 (2020). Special Edition-2020. P. 41-53. URL: http:// 
revista.sangregorio.edu.ec/index.php/REVISTASANGREGORIO/rt/metadata/1537 /5 (дата звернення: 14.02.2021).

22. Open Data in Europe 2020. European Data portal. URL: https://www.europeandataportal.eu/en/dashboard/2020 (дата звернення: 14.02.2021).

\section{References:}

1. USAID (2021), "Transparency and Accountability in Public Administration and Services", available at: https:/ /tapas.org.ua/all-uk (Accessed 14 Feb 2021).

2. Lviv open data portal (2021), available at: https:// opendata.city-adm.Iviv.ua (Accessed 14 Feb 2021).

3. Hryschenko, I.M. and Horbata, L.P. (2020), "Priority areas and ways to ensure information openness in public authorities", Public and municipal administration: theory, methodology, practice: Collective monograph., Izdevnieciba "Baltija Publishing", Riga, Latvia, pp. $20-39$.

4. Hryschenko, I. P (2020), "Program of activities of the Cabinet of Ministers of Ukraine in the aspect of consolidation and development of the ukrainian", Zbirnyk naukovykh prats' Natsional'noi akademii derzhavnoho upravlinnia pry Prezydentovi Ukrainy, vol. 1, pp. 33-40, available at: http://zbirnyk-nadu.academy.gov.ua/ article/view/208994/209142 (Accessed 14 Feb 2021). DOI 10.36.030/2664-3618-2020-1-33-40.

5. Cabinet of Ministers of Ukraine (2016), Resolution "Some issues of accession to the International Open Data Charter", available at: https:/ / zakon.rada.gov.ua/laws / show /686-2016-\%D1\%80\#Text (Accessed 14 Feb 2021).

6. Durman, M.O. (2017), "Open data as a tool for information transparency of public authorities", Teoriia ta praktyka derzhavnoho upravlinnia i mistsevoho samovriaduvannia, vol. 1, available at: http://nbuv.gov.ua/j-pdf / Ttpdu_2017_1_15.pdf (Accessed 14 Feb 2021).

7. State open data web portal (2021), available at: http:/ /data.gov.ua (Accessed 14 Feb 2021).

8. NISS (2016), "Basic principles of use and access to public information in the form of open data: foreign experience for Ukraine", available at: http://www.niss.gov.ua/articles / 2297 / (Accessed 14 Feb 2021).

9. CityBot Nazar (2021), available at: https:// citybot.pro (Accessed 14 Feb 2021).

10. Open Data Charter (2021), "Government adopters", available at: https://opendatacharter.net/government-adopters (Accessed 14 Feb 2021).

11. Vinnytsia open data portal (2021), available at: https:/ /opendata.gov.ua (Accessed 14 Feb 2021).

12. Open Data Portal of the Dnipro City Council (2021), available at: https://opendata.dniprorada.gov.ua (Accessed 14 Feb 2021).

13. Drohobych City Council Open Data Portal (2021), available at: https://opendata.drohobych-rada.gov.ua (Accessed 14 Feb 2021).

14. Mariupol City Council Open Data Portal (2021), available at: https:/ / data.mariupolrada.gov.ua (Accessed 14 Feb 2021).

15. Open data portal of the Slov'yans'k City Council (2021), available at: https://opendata.slavrada.gov.ua (Accessed 14 Feb 2021).
16. Khmelnytsky City Council open data portal (2021), available at: https://mycity.khm.gov.ua/OpenData (Accessed 14 Feb 2021).

17. Chernivtsi open data portal (2021), available at: https:/ / data.city.cv.ua (Accessed 14 Feb 2021).

18. Cabinet of Ministers of Ukraine (2015), Resolution "On approval of the Regulations on data sets to be published in the form of open data", available at: https:// zakon.rada.gov.ua/laws/show /835-2015-\%D0\%BF\#Text (Accessed 14 Feb 2021).

19. Verkhovna Rada of Ukraine (2015), The Law of Ukraine "On amendments to some laws of Ukraine on access to public information in the form of open data", available at: http://zakon.rada.gov.ua/go/319-19 (Accessed 14 Feb 2021).

20. Cabinet of Ministers of Ukraine (2017), Resolution "On Amendments to the Regulations on Data Sets to be Disclosed in the Form of Open Data", available at: http:/ /zakon5.rada.gov.ua/laws/show/1100-2017-p (Accessed 14 Feb 2021).

21. Semenyshyn, M. O. Hryshchenko, I. M. Alekseieva, K. A. Oliinyk, V. V. and Buha, H. S. (2020), "Research of features of professional self-actualization of civil servants through the determinants of information security", Revista San Gregorio, vol. 42, Special Edition-2020, pp. 41-53, available at: http://revista.sangregorio.edu.ec/ index.php/REVISTASANGREGORIO/rt/metadata / $1537 / 5$ (Accessed 14 Feb 2021).

22. European Data portal (2020), "Open Data in Europe 2020", available at: https://www.europeandataportal.eu/en/dashboard/2020 (Accessed 14 Feb 2021).

Стаття надійшла до редакиї 14.02.2021 p. www. dy.nayka.com.ua

Електронне фахове видання

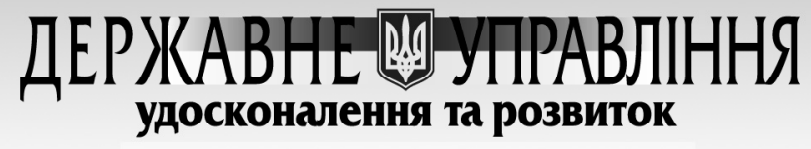

Виходить 12 разів на рік

включено до переліку наукових фахових видань України З ПИтань ДЕРЖАВНОГО УПРАВЛІННЯ

(Категорія «Б»)

Наказ Міністерства освіти і науки України від 28.12.2019 №1643

Спеціальність 281

e-mail:economy_2008@ukr.net

тел.: (044) 223-26-28, (044) 458-10-73 